\title{
Factors Affecting Marital Maintenance Behaviors in Economic Pressure from Married Women's Perspective
}

\author{
Nasim Sheikhi-Fini ${ }^{1}$, Hosein Salimi-Bajestani2 ${ }^{*}$, Ebrahim Naeimi $^{2}$ \\ 1. M.A. in Family Counseling, Allameh Tabataba'i University, Tehran, Iran \\ 2. Associate Professor of Counseling, Allameh Tabataba'i University, Tehran, Iran \\ 3. Assistant Professor of Counseling, Allameh Tabataba'i University, Tehran, Iran \\ * Corresponding author's Email: H.salimi.b@gmail.com
}

\begin{abstract}
The current study intended to identify the factors influencing marital maintenance behaviors in economic pressure periods from married women's perspective. In so doing, a qualitative approach and a phenomenological research methodology was employed. The participants included 15 married women living in Bandar Abbas who were selected through purposive sampling method. The data were collected through semi-structured interviews and were analyzed using Thematic Analysis (TA) technique. The results revealed that the behaviors that maintain the couple's relationship included a main theme, i.e. the behaviors that maintain the couple's relationship. Sub-themes of factors related to couple maintenance behaviors included managing economic conditions, counseling and psychological services, main and core family interaction, and life skills. These findings can be used in the field of divorce prevention and family strengthening.
\end{abstract}

Keywords: Maintenance behaviors, economic pressure, marital relationship, married women

\section{Introduction}

The family is the most important foundation of society in which people grow and enter society as a result of interaction with other members. Accordingly, the strength of society, which is characterized by a large structure, depends entirely on the strength of its pillars, namely the family. Nowadays, moral issues, emotional crises, and entanglement in relationships make the family very worried, and any dysfunction in the family causes social problems and the collapse of society (Khodayarifard, Zandi, Hajhosseini, \& Ghobari, 2017). In recent decades, the family has faced new issues such as the lack of commitment of spouses and the lenient attitude towards divorce. This is called crisis in the family. This crisis is partly due to inattention to the cultural context and socio-historical characteristics of society with modernization (Zahedi \& Nazkatbar, 2014). The change of family institution from traditional to modern in Iran in recent decades is mostly due to modernization and cultural changes, which has led to the education of a modern generation which has endangered the stability of the family with its new ideas such as denying gender differences (Eslamzadeh, Esmaeily, \& Kazemiyan, 2017). Changing the role and status of women, increasing divorce rates, declining marriages, changing attitudes toward the role of spouses, lack of focus on decision-making in families, and harms such as divorce and unfaithfulness of spouses to each other 
may be signs of disorganization of the family institution in the adjacent future. Because the structure of the family, family relations, the institutional position of the family and their relationships with other institutions of society can lead to many social problems. Today, family crises may have a significant negative impact on the economic and social development of society. Concerns about the family and its status are not unique to our society, but have threatened the globalization of the family in most societies; Therefore, any change in the family leads to a change in the social system. One of the main consequences of these changes is the creation of a broken family, which results in the emergence of stagnant and critical social issues such as the collapse of the family in society (Ashrafi, Qayyumi, \& Ameri Shahrabi, 2019). In recent years, Iranian society has faced significant changes along with the structural and technical changes, extensive connection with the international community, as well as familiarity with the system of new values in the world. Values and attitudes about the institution of the family, marriage, and methods of choosing a spouse have been among the areas that have undergone extensive changes so that it can be said that the cultural values of Iranians are being rebuilt. The process of mixing values during the transition from traditional to modern society is associated with incompatibility and value multiplicity which can create a harmful challenge in societies such as Iran (Movahhed \& Abbasi Shavazi, 2006).

Some biologists believe that certain biological factors play a role in choosing a mate. This view is based on the theory of evolution: humans instinctively choose couples that seek the survival of their species (GermanMaghdoor, 2014). To be more simple, failure to choose the right spouse or to maintain a spouse until reproduction prevents the reproduction of one person (Buss, 2007). On the other hand, intimate relationships are exposed to weakening over time, but with preventive care, it is possible to improve and strengthen the couple's relationship before the relationship weakens (Stafford, 2020). Research on the stability and maintenance of the marital relationship has always been of interest to researchers, and the study of behaviors that maintain the relationship continues (Ogolsky \& Monk, 2019).

Behaviors that maintain a marital relationship include confidence (reassurance to your partner about commitment in the relationship), openness in the relationship (talking about the relationship and each other's needs), being positive (being pleasant, being happy for the partner), social networks (relying on mutual friends and family members to achieve the goals of the marital relationship), task division (agreeing on how to perform tasks), willingness to manage conflict in the marital relationship and consulting (Dainton, 2019).

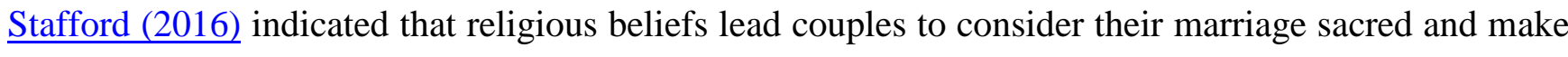
more efforts to maintain the marriage. Maintaining the dignity of the spouse in the marital relationship increases the quality of the marital relationship and leads to preservation. And maintenance of the relationship. Dainton, Goodboy, Borzea, and Goldman (2017) showed that distance, uncertainty, and induction of jealousy are negative and destructive behaviors for a relationship maintaining. Clark, Votaw, Harris, Hasan, and Fernandez (2020) revealed that social communication increases the motivation of couples to maintain and support maintenance behaviors. Danton (2019) showed that satisfaction with the 
first marriage predicts maintenance behaviors in people who remarry. Maier, Turkiewicz, and Herrman (2019) indicated that the division of responsibilities of couples in life is associated with relationship satisfaction and efforts to maintain the marital relationship. Stafford (2020) designated that low value rewards compared to the expenses incurred by individuals in marriage have led to a reduction in the maintenance behaviors of couples. LeBaron et al. (2020) demonstrated that in the economic pressure, the maintenance behaviors of couples' increase. Stafford (2020), in a study of 309 couples, showed that collective power (family and friends) leads to increased couples' maintenance behaviors. In economic crises, the family faces more challenges. Research by Dew (2007), Archuleta, Britt, Tonn, and Grable (2011), as well as Ellison, Henderson, Glenn, and Harkrider (2011) have indicated that economic problems lead to individual, marital, and family problems. Economic pressure has an irreversible effect on the quality of the couple's relationship. Therefore, supportive behaviors of couples are important to protect the family from the damage of economic issues (Dew \& Xiao, 2013). Economic problems negatively affect marital satisfaction. Economic factors are one of the factors affecting the commitment of couples, and can lead to marital relationship problems and pave the way for separation (Dew \& Xiao, $\underline{2013})$.

Families in economic crises can manage the crisis in different ways. Economic pressures have increased the focus on the family in economic crisis and economic hardship. When families do not have a good source of income, they temporarily increase their tolerance for difficult situations. Therefore, they use their savings or use other means such as getting help from others instead of getting loan. If families expect their future income to be lower, they will not take out more loans. On the other hand, some families have turned to second and third jobs to finance their debts, and this has created a difficult situation for family members, which requires the sacrifice of family members to overcome this crisis (Beck \& Dioni, 2010). Stress from financial problems often causes psychological distress and can lead to poor parenting and damage to the couple's relationship. Stress can negatively affect parenting as well as the physical and emotional health of couples (Dave \& Jorgason, 2010). Understanding how economic conditions affect families helps affected families. When couples are economically stressed, men are more violent and women are less positive about their relationships than their husbands (Scarmala, Sahrpertson, Cohan, \& Mirabil, 2008). Economic pressure increases the difference between couples and reduces the satisfaction of the couple's relationship and the support of the spouses. Ultimately, these factors negatively affect couples, increase marital conflicts, and decrease marital satisfaction (Stuart, Dave, \& Lee, 2017).

Given the rate of inflation, price rises and increasing economic pressure in Iran, one of the factors threatening the foundation of the family can be economic factors and conflicts arising from financial issues in the relationship between couples. On the other hand, in the study of couple maintenance behaviors, due to the involvement of cultural factors, the type of couple maintenance behaviors can be different. However, so far, little research has been done to identify the behaviors that maintain the couple's relationship in the economic crisis, and this issue has been somewhat ignored. Therefore, the 
aim of this study was to identify the factors affecting the maintenance behaviors of couples in the period of economic pressures from the perspective of married women.

\section{Material and Method}

The present study was conducted with a qualitative approach within phenomenological method. The study population was married women in Bandar Abbas in 2019. The sampling method was purposive sampling for selecting participants in this study. The statistical sample included 15 married women living in Bandar Abbas. The demographic information of the study participants is presented in Table 1. Criteria for entry of participants into the research were: 1. Feeling the economic pressure, and 2. having interest, sufficient time and complete satisfaction to participate in the interview. To conduct the research, first, an announcement was made to invite the participants to participate in the research. The announcement was distributed via social media. Then, from the participants who were volunteer to be interviewed, those who met the inclusion criteria were selected and a semi-structured interview was conducted with them. Each interview lasted about 40 minutes, and the content of the interview was audio-recorded. Then, the content of the interview was transcribed verbatim, coded and analyzed. The data obtained from the interview were analyzed through content analysis method. The first step in this method is to get acquainted with the data. The second step is to create the initial code. At this stage, the researcher studied the data and compiled an initial list of data. In this step, the code was used to divide the textual data into comprehensible and usable parts, such as a phrase, word, or other criteria needed for specific analysis. The third step is to search and identify the themes, focusing on the analysis the codes at a deeper level. Different codes were arranged and coded in the form of themes.

There are different criteria for validation in qualitative research. In this study, an attempt was made to suspend the researcher's prior knowledge and assumptions, and to record the original experiences of the participants. Member checking was used to ensure the validity of the data. That is, after the analysis, the interview data were returned to the interviewee to confirm the accuracy of the content, and make the necessary changes. In order to confirm the reliability and adequacy, the peer review method was used. In other words, to ensure the accuracy of the work process, part of the data analysis and code extraction was re-conducted by the professors supervising the research and a qualitative research expert.

\section{Ethical considerations}

In the current study, the information of the interviewees was used without mentioning their name and surname, and the interviewees were assured about the confidentiality of the information. Conscious consent was also obtained from the participants. Individuals participating in the interview were informed about aims of the research. Moreover, the interviewees were free to leave the research process whenever they wished. 
Table 1. Demographic characteristics of the interviewees

\begin{tabular}{|c|c|c|c|c|c|c|c|}
\hline ID & $\begin{array}{c}\text { Woman } \\
\text { age }\end{array}$ & $\begin{array}{c}\text { Occupational status } \\
\text { of woman }\end{array}$ & $\begin{array}{c}\text { Age of } \\
\text { man }\end{array}$ & $\begin{array}{c}\text { Job status of the } \\
\text { man }\end{array}$ & $\begin{array}{c}\text { Marriage } \\
\text { duration }\end{array}$ & $\begin{array}{c}\text { N of } \\
\text { children }\end{array}$ & $\begin{array}{c}\text { Economic status } \\
\text { of the family }\end{array}$ \\
\hline 1 & 26 & housewife & 26 & Freelance & 3 & 0 & Weak \\
\hline 2 & 30 & government job & 35 & Freelance & 6 & 1 & Good \\
\hline 3 & 40 & government job & 40 & government job & 19 & 2 & Good \\
\hline 4 & 49 & government job & 53 & government job & 25 & 3 & Moderate \\
\hline 5 & 31 & government job & 32 & government job & 5 & 1 & Moderate \\
\hline 6 & 38 & government job & 40 & government job & 3 & 0 & Weak \\
\hline 7 & 38 & government job & 38 & Freelance & 12 & 1 & Good \\
\hline 8 & 44 & government job & 40 & government job & 20 & 1 & Moderate \\
\hline 9 & 38 & government job & 41 & government job & 20 & 3 & Moderate \\
\hline 10 & 34 & government job & 34 & government job & 6 & 2 & Weak \\
\hline 11 & 24 & Freelance & 30 & Freelance & 4 & 0 & Moderate \\
\hline 12 & 25 & housewife & 28 & Freelance & 3 & 0 & Weak \\
\hline 13 & 23 & housewife & 32 & government job & 3 & 0 & Moderate \\
\hline 14 & 26 & Freelance & 30 & Freelance & 6 & 0 & Weak \\
\hline 15 & 59 & housewife & 60 & Freelance & 36 & 3 & Moderate \\
\hline
\end{tabular}

\section{Results}

To answer the research question (i.e., What are the behaviors that maintain the relationship between couples during economic pressures from the perspective of married women?), the results of content analysis are provided in Table 2 .

Table 2. Main, sub-themes and concepts of maintenance behaviors

\begin{tabular}{|c|c|c|}
\hline The main theme & Sub-theme & concepts \\
\hline \multirow{15}{*}{$\begin{array}{l}\text { Factors related to couple } \\
\text { maintenance behaviors }\end{array}$} & \multirow{4}{*}{$\begin{array}{l}\text { Managing economic } \\
\text { conditions }\end{array}$} & contentment and avoidance of consumerism \\
\hline & & cost management \\
\hline & & Participation in money making \\
\hline & & Avoiding the one-upmanship \\
\hline & \multirow[t]{5}{*}{$\begin{array}{c}\text { Counseling and } \\
\text { psychological services }\end{array}$} & $\begin{array}{c}\text { Striving for personal growth to prevent divorce and } \\
\text { greater commitment }\end{array}$ \\
\hline & & Use of psychological books and magazines \\
\hline & & Positive energy and positivity \\
\hline & & Consulting \\
\hline & & Avoiding sharing problems to others \\
\hline & \multirow{3}{*}{$\begin{array}{l}\text { Main and core family } \\
\text { interaction }\end{array}$} & Good relationship with spouse family \\
\hline & & $\begin{array}{l}\text { Maintaining balance on the boundaries between the } \\
\text { main and core families }\end{array}$ \\
\hline & & Supporting the spouse's family \\
\hline & \multirow[t]{3}{*}{ Life Skills } & Anger control \\
\hline & & Sacrifice and forgiveness \\
\hline & & Respect \\
\hline
\end{tabular}


The results of content analysis have revealed that the behaviors that maintain the couple's relationship include the content of factors related to the couple's maintaining behaviors that are introduced as follows.

\section{1-Management of economic conditions}

Managing economic conditions includes contentment and avoidance of consumerism, cost management, participation in money making, and avoidance of one-upmanship.

\section{-Contentment and avoidance of consumerism}

Contentment and avoidance of consumerism refers to saving on living costs and avoiding additional costs. As an example, one of the participants (a 23-year-old woman) stated:

"We are consumerists in our country as a whole, and well, really give this a lot, and in these circumstances we have to reduce our expenses, for example, when we want to have a party, or for example, in buying clothes, I think we are very consumerist and we should be economical."

\section{-Cost management}

Cost management refers to managing how money is spent and family finances planning. As an example, one of the participants (26 years old) stated:

" When I see difficult economic conditions, I plan what model to spend, what my expectations are, and I have that in mind."

\section{-Participation in money making}

Money making participating refers to a couple's participation in earning money and sharing income in their life together. As an example, one of the participants (26 years old) stated:

"I see in my own life that we are both working. I try not to put extra burden on him. If a man can, he should lift a burden from his wife and work to make money in economic pressure. I have to be with my husband. It is not anybody's fault. In any case, I have to get along somehow. If he works, I will work alongside him and do not say that only he is in charge of providing expenses. "

\section{-Avoiding one-upmanship}

Abstaining from one-upmanship refers to avoiding comparing one's life with the lives of others. As an example, one of the participants (26 years old) stated:

" The housewife should not compare her husband with other men, what they have and what you do not have. "We live to the extent that we have and we do not compare our lives with others, what others have and what we do not have, that is, we spend according to our income and expenses."

\section{2- Counseling and psychological services}

Counseling and psychological services include trying to grow as a person to prevent divorce and greater commitment, using psychological books and magazines, positive energy and positivity, counseling and avoiding sharing problems with others.

\section{- Striving for personal growth in order to prevent divorce and provide greater commitment}

Striving for personal growth to prevent divorce and provide greater commitment refers to each couple's efforts to grow individually to acquire life skills and marital adjustment. As an example, one of the participants (38 years old) stated:

"I never personally find divorce as a strange issue, but I try to work on myself, hence, it did not happen." 


\section{- Use of psychology books and magazines}

This theme refers to the couple's use of psychology books and magazines and psychological content that is shared in cyberspace in the couple's married life. As an example, one of the participants (24-year-old woman) stated:

"Instagram psychology pages are not all scientific, and if they are scientific, it depends on your point of view, and the page that is closest to my lifestyle and beliefs, well, it affects me a lot, especially those who have a scientific article behind them, so it has a great effect on me. I read and use it and send it to my husband. One of the things I learned from the psychology pages of Instagram was a minimal lifestyle, that is, in this economic pressure, I try to do a lot of things and have a lot of things at the basic level. If you are not satisfied with less, you will be really annoyed, and those who say you should think too much, and if you are not satisfied with less, they will be annoyed that they will pursue high and ideal goals, and if you cannot reach those goals, you will be disappointed later. "In these economic circumstances, if I want to buy a Benz car, I think I will be disappointed, and in this economic situation, I think I should not think of a car better than the Peugeot 206, because otherwise I will be annoyed."

\section{- Positive energy and positivity}

Positive energy and positivity refers to the positivity and happy mood of couples in life. As an example, one of the participants (38 years old) stated:

"I personally tried to put maximum energy and ability in my life for my husband and children, for example, when I go home from work, I go home with a happy face, and also due to the positive energy and happiness of a spouse, the mate and family will be happy».

\section{-Counseling}

Counseling refers to the role of psychological counseling in how to solve couples' life problems. As an example, one of the participants (38 years old) stated:

"I have a friend who is a counselor, and if I have a problem, I call him immediately and get counseling about what kind of behavior should I do and what should not I do? I was able to positively change my husband's view of counseling by working on myself and get help from a consultant. My husband and I were very young when we got married and on the other hand, we did not have experienced mothers to teach us anything about solving marital problems. "Well, you have to learn this from someone and who is better than a consultant."

\section{- Avoiding sharing the problems to others}

- Avoiding sharing the problems to others refers to not saying the problems of couples to familiar people and relatives. As an example, one of the participants (38 years old) stated:

"I tried to never tell my personal family problems anywhere and keep them only between myself and my husband, which means that even my family members are not informed of many issues. I always tried to solve marital problems between us or if I wanted to tell a stranger, a friend, someone, I told a counselor because I know if I tell my mother, the problem cannot be solved because mothers are emotional, they say your husband has done something wrong, then your husband may lose the social image he had in your family earlier, and if this happens, your husband's return to the family will be very difficult ». 
3- The interaction of the core and core family includes a good relationship with the spouse's family, maintaining a balance between the main and core family, and supporting the spouse's family.

\section{- Good relationship with the spouse's family}

A good relationship with the spouse's family refers to a couple's good relationship with their spouse's family. For example, one of the participants (a 24-year-old woman) stated, "When my husband's family is coming to our home, I always try to be welcoming and very respectful. I also respect my husband in front of his family. My husband also has a good family and a very good behavior with my family. "He has acceptance with my family and respects them very much."

\section{- Maintaining balance on the boundaries between the main and core family}

Maintaining balance at the boundaries between the main and core families refers to maintaining the boundaries between the main and core families. As an example, one of the participants (a 40-year-old woman) stated:

"My husband has never allowed even one of his family members to say a bad thing about me".

\section{- Supporting the spouse's family}

Supporting the spouse's family refers to financial and affective support of the spouse's family in times of trouble. As an example, one of the participants (59 years old) stated:

"My husband has always been financially, affective and behaviorally supportive, not only of me but also of my family, and I have always been able to count on my husband's support in difficult economic times and even illness."

\section{4- Life skills}

Life skills include anger management, self-sacrifice, and forgiveness and respect.

\section{- Anger management}

Anger management refers to a couple's ability to control their anger in the face of difficult situations. As an example, one of the participants (38 years old) stated:

"There are some people who are always against their husbands' investments. I tried, even if I were against it, to tell my husband very calmly and peacefully that if we do not do that, it would be better. If my husband did an economic work and went bankrupt or had financial problems, I would not blame him saying that it would have been better if you had not done this, because everyone takes risks at some point".

\section{- Sacrifice and forgiveness}

Sacrifice and forgiveness refers to the skill of self-sacrifice and forgiveness of the spouse in the challenges of married life. As an example, one of the participants (59 years old) stated:

"There are many things in life that I have forgiven my husband. "In any case, we should try to maintain the relationship. Maybe because of this, I did not put my husband in difficulty in life."

\section{- Respect}

Respect refers to the couple's maintaining respect for each other in front of other people. As an example, one of the participants (a 40-year-old woman) stated: 
"My husband respects me a lot in front of others. " That's why others always praise my husband for respecting me and my husband is a model for others."

\section{Discussion}

The aim of this study was to investigate the factors affecting the behaviors that maintain the relationship between couples in times of economic stress from the perspective of married women. The first finding of this study was management of economic conditions. One of the factors was contentment and avoidance of consumerism. The findings of this study indicated that since 2018, Iran faced an economic crisis along with the increase of the dollar rate and sanctions against Iran on behalf of foreign countries, and inflation rate. These factors led the couples to conclude that they were content with economic pressures and avoided consumerism in order to maintain their relationship. Another factor was cost management. The findings of current study suggested that couples plan to maintain their relationship based on their income and calculate their economic expectations based on their income and expenditure. Another factor was participation in money making. The women came to the conclusion that in order to maintain their lives, they had to work alongside their husbands and share in the income making with their husbands. With the economic crisis, a new field of women's participation in women's social activities has been created. Another factor was avoiding one-upmanship. The findings of the present study indicated that in the economic crisis, women gave up the one-upmanship habit to protect their lives from economic pressure because this wrong habit makes the pressures of the economic crisis worse. This finding is consistent with the results of LeBaron et al. (2020).

Another factor was the use of counseling and psychological services. One of the factors was striving for personal growth in order to prevent divorce and be more committed. The findings from this study indicated that couples work on their personality development to maintain their marriage. This finding is in line with the humanistic approach. The humanistic approach always considers man to be growing and flourishing, and man has an innate tendency to grow and flourish. This approach has also dealt with couples' relationships, and believes that if marriage prevents a couple from developing, it will cause differences and separation (Pearson \& Podeschi, 1999). Another factor was the use of psychology books and magazines. The findings of this study indicated that in recent years, one of the effective virtual trainings in maintaining and strengthening the relationship between couples is the use of psychological content in cyberspace. In this way, couples share psychological materials with each other and apply them in their married life. Another factor was positive energy and positivity. The findings of this study indicated that positive energy and positivity lead to the transfer of this positive energy to the spouse and family, and it seems to increase life satisfaction and maintaining a marital relationship. Another factor was counseling. The findings of this study indicated that due to the complexity of relationship issues between couples, they have seen the need for counseling to maintain their relationship, which has become more prominent in recent years. Another factor was avoiding sharing problems with others. The results 
of this study suggested that couples should maintain family privacy. These findings are consistent with the findings of Stafford (2016), Clark et al. (2020), and Stafford (2020).

Another factor was the interaction of the core family. One of the factors was a good relationship with the spouse's family. The findings indicated that good interaction with the spouse's family leads to more respect and preservation of dignity, so it seems that one of the factors affecting the stability and maintenance of couples is good interaction with the spouse's family. Another factor was maintaining a balance between the main and core families. Another factor was supporting the spouse's family. The findings of this study indicated that one of the rights of spouses to each other is respect and attention to the spouse's family and financial and emotional support of the couple to their parents and the spouse's family, which can lead to maintaining the couple's relationship. These findings are consistent with the findings of Stafford (2016), Clark et al. (2020), and Stafford (2020).

Another factor was life skills. One of these skills was anger management. The findings of the present study indicated that anger management causes people to choose a problem-oriented strategy in crises. Anger control and problem-solving strategies can help maintain a couple's relationship during economic crises. Another factor was self-sacrifice. The findings of this study showed that many people consider self-sacrifice and forgiveness as a religious teaching. Another factor was respect. The findings of this study demonstrated that respect and attention to the spouse as well as the spouse's family is one of the rights of spouses. Respect for the spouse's family creates mutual respect, i.e. respect for the spouse and the spouse's family is a large part of the commitment to stay in life, and respect and attention to the spouse's family paves the ground for maintaining the marriage. These findings are consistent with the results of Stafford (2016).

As a result, in general, the maintenance behaviors of couples are influenced by a number of cultural and family factors, the relationship between the core and main families, the personality characteristics of each couple and the couple's use of psychological teachings and counseling, and the level of life skills. These factors have led to the couple's ability to cope with the economic crisis and have helped maintain the couple's relationship.

Conflict of interest: The authors stated no conflict of interest in the study.

Financial sponsor: The authors acknowledged that they he not received any financial support for all stages of the study, writing and publication of the paper.

\section{References}

Archuleta, K. L., Britt, S. L., Tonn, T. J., \& Grable, J. E. (2011). Financial satisfaction and financial stressors in marital satisfaction. Psychological reports, 108(2), 563-576.

Ashrafi, Z., Qayyumi, A., \& Ameri Shahrabi, M. (2019). Investigating the Impact of Cultural Globalization on Creating Structural and Functional Changes in the Family (Case Study: Women Working in Tehran Municipality, District 7). Research of Nations, 4(42), 107-121. 
Buss, D. M. (2007). The evolution of human mating. Acta Psychologica Sinica, 39(3), 502-512.

Clark, E. M., Votaw, K. L., Harris, A. L., Hasan, M., \& Fernandez, P. (2020). Unrequited love: The role of prior commitment, motivation to remain friends, and friendship maintenance. The Journal of social psychology, 160(3), 293-309.

Dainton, M. (2019). Equity and relationship maintenance in first marriages and remarriages. Journal of Divorce \& Remarriage, 60(8), 583-599.

Dainton, M., Goodboy, A. K., Borzea, D., \& Goldman, Z. W. (2017). The dyadic effects of relationship uncertainty on negative relational maintenance. Communication Reports, 30(3), 170-181.

Dew, J. (2007). Two sides of the same coin? The differing roles of assets and consumer debt in marriage. Journal of Family and Economic Issues, 28(1), 89-104.

Dew, J., \& Xiao, J. J. (2013). Financial declines, financial behaviors, and relationship happiness during the 2007-2009 recession. Journal of Financial Therapy, 4(1), 1-20.

Ellison, C. G., Henderson, A. K., Glenn, N. D., \& Harkrider, K. E. (2011). Sanctification, stress, and marital quality. Family Relations, 60(4), 404-420.

Eslamzadeh, B., Esmaeily, M., \& Kazemiyan, S. (2017). Qualitative Analysis of checking the Role of Community Modernization with Virtual Media on Family Structure. Counseling Culture and Psycotherapy, 8(31), 133-164.

GermanMaghdoor, M. (2014). The effectiveness of mindfulness training on changing dysfunctional attitudes in choosing a spouse. (M.A.), Allameh Tabatabaei University, Tehran.

Khodayarifard, M., Zandi, S., Hajhosseini, M., \& Ghobari, B. B. (2017). Efficacy of positive thinking training on the family process and subjective wellbeing of female heads of household. $J$ Fam Res, 12 , 593-612.

LeBaron, A. B., Curran, M. A., Li, X., Dew, J. P., Sharp, T. K., \& Barnett, M. A. (2020). Financial stressors as catalysts for relational growth: Bonadaptation among lower-income, unmarried couples. Journal of Family and Economic Issues, 1-18.

Maier, M., Turkiewicz, K., \& Herrman, A. R. (2019). Relational maintenance strategies and satisfaction in the stepmother-stepdaughter dyad. The Family Journal, 27(4), 377-386.

Movahhed, M., \& Abbasi Shavazi, M. T. (2006). Traditional And Modern Values Among Girls Residing In Shiraz. WOMENS STUDIES, 4(1), 67-99.

Ogolsky, B. G., \& Monk, J. K. (2019). Relationship maintenance: Theory, process, and context: Cambridge University Press.

Pearson, E. M., \& Podeschi, R. L. (1999). Humanism and individualism: Maslow and his critics. Adult Education Quarterly, 50(1), 41-55.

Stafford, L. (2016). Marital sanctity, relationship maintenance, and marital quality. Journal of Family Issues, 37(1), 119-131.

Stafford, L. (2020). Communal strength, exchange orientation, equity, and relational maintenance. Journal of Social and Personal Relationships, 37(8-9), 2345-2365.

Zahedi, M., \& Nazkatbar, H. (2014). Crisis modernization and changes in the family (study of new family issues in urban areas of Mazandaran province). . Social Studies and Research in Iran, 3(3), 257-282.

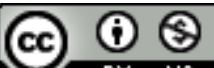

BY NC This work is licensed under a Creative Commons Attribution-Noncommercial 4.0 International License 